\title{
Valstybinių parkų kraštovaizdžio morfostruktūros analizè: 2. Teritorijos išskirtinumas
}

\author{
Paulius Kavaliauskas', \\ Nedmantas Kavaliauskas ${ }^{2}$ \\ ${ }^{1}$ Vilniaus universitetas, \\ M. K. Čiurlionio g. 21, 03101 Vilnius \\ El.paštas paulius.kaval@gmail.com \\ ${ }^{2}$ VI Valstybès žemès fondas, \\ Konstitucijos pr. 23-419, 08105 Vilnius \\ El.paštasnedmantas@gmail.com
}

Kavaliauskas P., Kavaliauskas N. Valstybinių parkų kraštovaizdžio morfostruktūros analizė: 2. Teritorijos išskirtinumas. Geologija. Geografija. 2019. T. 5(2). ISSN 2351-7549.

Straipsnis prezentuoja 2018-2019 m. atliktos visų Lietuvos nacionalinių ir regioninių parkų kraštovaizdžio struktūros analizès antrosios dalies, skirtos teritorijų santykiniam išskirtinumui aptarti, rezultatus. Jame pateikiami kraštovaizdžio išskirtinumo sampratos ypatumai, bandymai ji nustatyti ir užsienio bei Lietuvos patirtis šioje srityje. Pristatoma naujausia originali kraštovaizdžio išskirtinumo analizės metodika, kuri buvo adaptuota Lietuvos nacionalinių ir regioninių parkų teritorijoms. Teikiamas gautas šių 35 parkų kraštovaizdžio morfostruktūros įvairovės ir kompleksinès vertès palyginamojo vertinimo rezultatų apibendrinimas.

Specialus dèmesys skirtas palyginamajai išskirtinei kraštovaizdžio struktūros ịvairovei nustatyti, naudojant suminị išskirtinės ịvairovès koeficientą. Antra vertus, kraštovaizdžio struktūros palyginamoji išskirtinė vertė gali būti skaičiuojama kitais dviem alternatyviais būdais: (a) pagal kraštovaizdžio apylinkių kompleksinio vertinimo metu surinktą bendrą išskirtinumo balų sumą ir (b) pagal išskirtinius balus gavusių kraštovaizdžio apylinkių plotų suminị procentą. Atsižvelgiant ị vertinimo rezultatus visi nacionaliniai ir regionai pirkai skirstomi į aukščiausio, didelio bei standartinio teritorijos išskirtinumo (santykinio vertingumo) grupes.

Raktažodžiai: nacionaliniai ir regioniniai parkai, kraštovaizdžio morfostruktūra, kraštovaizdžio įvairovė, kraštovaizdžio kompleksinè vertė, teritorijos išskirtinumas

\section{IVADAS}

Lietuvos saugomų teritorijų kraštovaizdžio struktūros gilesnio pažinimo ir jų kraštotvarkos organizavimo klausimai iki šiol išlieka aktualūs tiek metodologine, tiek ir praktine prasmèmis. Saugomų teritorijų naudojimo ir apsaugos optimizavimo interesai reikalauja turèti moksliškai pagrịstas nuostatas dèl jų kraštovaizdžio struktūros ir galimos raidos kelių, privalu laikytis visuomenès interesus atitinkančios jų kūrimo ir tvarkymo metodologijos (Kavaliauskas, 1986). Deja, kraštovaiz- džio pažinimui mūsų šalyje iki šiol nebuvo skirta pakankamai dèmesio, dar gyva tradicija vengti ir ignoruoti arba nepagristai susiaurintai vartoti patị ši terminą, painioti kraštovaizdị su gamtine aplinka ar želdiniais, kas ypač ryšku urbanistikoje. Dèl to atsiranda ir tokie reiškiniai kaip ịvairių kraštovaizdžio sampratos variantų painiojimas, veiksmingos kraštovaizdžio planavimo sistemos nebuvimas, nepakankamas kraštovaizdžio integravimas i̇ kompleksinį teritorijų planavimą, ydingas metodologinis ir teisinis kraštovaizdžio planavimo bei kraštovaizdžio projektavimo 
(kraštovaizdžio architektūros) painiojimas ir pan. Suprantama, kad visa tai ypač nepageidautina kalbant apie saugomas teritorijas, pirmiausia valstybinius (nacionalinius ir regioninius) parkus.

Per pastarąji dvidešimtmetị mūsų šalyje ịvyko svarbių teigiamų poslinkių, susijusių su Europos kraštovaizdžio konvencijos (European landscape..., 2001; Europos kraštovaizdžio..., 2001; Recommendation CM/Rec..., 2008) ratifikavimu, Lietuvos Respublikos kraštovaizdžio politikos krypčių aprašo (Lietuvos Respublikos..., 2004) ir Nacionalinio kraštovaizdžio tvarkymo plano (Kavaliauskas, Kažienè ir kt., 2015) patvirtinimu. Deja, pakeistame LR teritorijų planavimo i̇statyme (Lietuvos Respublikos..., 2013) buvo atsisakyta tiek minètuc dokumentų pagrindu parengtų galiojusių „Kraštovaizdžio tvarkymo specialiųjų planų rengimo taisyklių“ (Kraštovaidžio tvarkymo..., 2004), tiek optimizuotos naujos jų redakcijos (Kraštovaizdžio schemų..., 2013; Kavaliauskas, 2014), kas smarkiai apsunkino visuose minètuose dokumentuose deklaruotų kraštovaizdžio sampratos, analizès ir tvarkymo nuostatų realizavimą.

Vis dèlto ịgyvendinant pagal naująą kraštovaizdžio geografiją (Kavaliauskas ir kt., 2013) pradètą šalies kraštovaizdžio struktūros analizę Valstybinè saugomų teritorijų tarnyba (VSTT) $2017 \mathrm{~m}$. èmèsi dar vieno labai svarbaus darbo šalies saugomų teritorijų kraštovaizdžio pažinimui plèsti - buvo užsakyta parengti valstybinių parkų (VP) kraštovaizdžio struktūros schemas ir tai atlikti po atitinkamo viešojo konkurso buvo patikèta Valstybès įmonei Valstybès žemès fondui (Valstybinių parkų..., 2018-2019). Šiam projektui buvo keliami du pagrindiniai uždaviniai: a) plèsti VP kraštovaizdžio struktūros bendrąji pažinimą priartinant ji prie atitinkamo biologinès ịvairovès teritorinio pažinimo lygio ir b) nustatyti VP saugojimo pagrindą lemiančias vidines didžiausios vertès teritorijas.

Pirmajam tikslui pasiekti skirtos metodologijos problema buvo pristatyta specialiame straipsnyje (Kavaliauskas, 2019), o dabartinio straipsnio, pratęsiančio pirmąją publikaciją, tikslas atskleisti kelią, kuriuo buvo eita siekiant antrojo tikslo, t. y. nustatant VP vidines didžiausią (išskirtinę) vertę turinčias arba reikšmingiausias teritorijas ir atliekant atitinkamą palyginamają atskirų parkų analizę. Keliami šie uždaviniai: 1) apibendrinti turimą kraštovaizdžio išskirtinumo vertinimo patirtį; 2) pristatyti Lietuvos VP kraštovaizdžio struktūros morfo- loginio išskirtinumo rekognoskuotei sukurtą ir pritaikytą vertinimo metodiką; 3) pateikti šalies nacionalinių ir regioninių parkų kraštovaizdžio išskirtinumo palyginamojo vertinimo suvestinę. Siekiant igyvendinti prisiimtus uždavinius buvo naudoti ịvairūs tyrimo metodai - mokslinès literatūros, internetinių šaltinių, planavimo dokumentų ir teisinių informacinių leidinių analizé, kartografinis ir matematinis modeliavimas, taip pat loginio tyrimo dedukciniai ir nededukciniai samprotavimų būdai.

Pažymètina, kad analogiško nacionalinès apimties nacionalinių ir regioninių parkų kraštovaizdžio vidinio išskirtinumo studijos, atliktos mokslinès kraštovaizdžio sampratos pagrindu, iki šiol nẻra parengta nei Europoje, nei Šiaurès Amerikoje. Todèl mūsų šalies patirtis realiai gali turèti ir tam tikrą tarptautinę metodologinę svarbą, ypač kalbant apie Europos kraštovaizdžio konvencijos realizavimą (Recommendation..., 2008).

\section{KRAŠTOVAIZDŽIO IŠSKIRTINUMO TYRIMŲ PATIRTIS}

Suprantama, kad atskirų valstybinių parkų ir jų atskirų arealų kraštovaizdis tokiuose kraštovaizdžio teritorine mozaika pasižyminčiuose regionuose kaip Vidurio Europa negali ir nèra identiškas savo struktūra ir vertès požymiais. Dèl to nustatant kraštotvarkos prioritetus kompleksinio pobūdžio valstybiniuose parkuose (isk. Baltijos šalis) neišvengiamai susiduriama su parkų teritorijos nelygiavertiškumo ir atitinkamo jų kraštovaizdžio vertinimo problema.

Šiuolaikiniai kraštovaizdžio tyrimai ir planavimas yra sukaupę nemažą metodologinę ir ypač praktinę patirti taikomųjų teritorijos tyrimų srityse (Kavaliauskas, 1993, 2011; Wascher, 2005; Calera, 2014 ir kt.), tarp jų ir saugomų teritoriju (Deckha, 1999; Roger, 2008; Kavaliauskas, Veteikis, 2014 ir kt.). Pažymètina, kad terminai „išskirtinè vertë“ (outstanding value) ir ypač „,išskirtinè visuotinè verté" (Outstanding Universal Value) vertinant kraštovaizdị ísitvirtino po to, kai 1972 m. lapkričio 16 d. UNESCO Generalinès asamblejos 17 sesijoje Paryžiuje buvo priimta Pasaulio kultūros ir gamtos paveldo apsaugos konvencija (Convention Conserning the Protection of the World Cultural and Natural Heritage) ir pradèta sudarinèti bei skelbti UNESCO Pasaulio 
paveldo vietovių sąrašus (Feiden, Johilehto, 1993; Droste et al., 1995; Lietuvos nacionalinè..., 2006).

Pagal Konvencijos igyvendinimo rekomendacijas (UNESCO..., 2008; The World..., 2014), kad teritorijos ir objektai būtų ittraukiami ị Pasaulio paveldo sąrašą, būtina atitikti vieną ar daugiau atitikimo Išskirtinei visuotinei vertei (IVV) kriterijų:

1) reprezentuoti žmogaus kūrybinị genijų;

2) eksponuoti svarbius žmogiškųjų verčių pokyčius bėgant laikui, kultūrinių regionų architektūroje, technologijoje, monumentaliajame mene, planuojant miestus ar kraštovaizdi:

3) būti vieninteliu ar bent ypatingu paliudijimu apie dar gyvą ar jau išnykusią kultūrinę tradiciją arba civilizaciją;

4) būti svarbiu architektūrinio ar technologinio pastatų ansamblio arba kraštovaizdžio pavyzdžiu, iliustruojančiu žymias žmonijos istorijos pakopas;

5) būti reikšmingu tradicinès gyvenvietès, žemènaudos ar jūronaudos pavyzdžiu, reprezentuojančiu kultūrą (ar kultūras), ar žmogaus ir aplinkos ryšius, ypač kai tai tampa pažeidžiama dèl negrižtamų pokyčių;

6) būti tiesiogiai ir glaudžiai susijusiais su gyvenimo tradicijomis, idejomis, viltimis, su išskirtinès visuotinès vertès meno ir literatūros kūriniais (kriterijus daugiausia naudotinas kartu su kitais);

7) apimti nuostabius gamtos reiškinius arba ypatingo gamtos grožio bei estetinès svarbos vietoves;

8) būti raiškiais Žemès evoliucijos pavyzdžiais, atspindinčiais jos metraští, vykstančius geologinius procesus Žemès paviršiaus formų raidoje arba svarbius jo geomorfologinius ir fiziografinius bruožus;

9) būti raiškiais pavyzdžiais, reprezentuojančiais vykstančius ekologinius ir biologinius procesus sausumos, gèlųjų vandenų, kranto ir jūrų ekosistemų bei augalų ir gyvūnų bendrijų evoliucijoje bei raidoje;

10) apimti svarbiausias ir žymiausias biologinès ivvairovès apsaugai in situ gamtines buveines, įskaitant turinčias universalią vertę mokslo ar išsaugojimo požiūriais pasižyminčių nykstančių rūšių.

Be to:

1. Visos siūlomos teritorijos ar objektai turi atitikti integralumo sąlygas, t. y:: IVV;

a) turi visus elementus, reikalingus išreikšti jų

b) yra tinkamo ploto, kad užtikrintų jų svarbą lemiančių bruožų ar procesų reprezentavimą;

c) kenčia nuo neigiamo poveikio ar nesirūpinimo.
2. Būtina išpildyti kultūrinès (1-6 kriterijai) ar gamtinès (1-6 kriterijai) vertès išlikimo testą.

Deja, nustatytas visuotinio (universalaus) išskirtinumo vertinimo kriterijų aprašas gali būti gana subjektyviai ir skirtingai traktuojamas bei neturi jokių parametrizacijos elementų. Tai pasaulyje kelia sunkiai išsprendžiamų problemų. Kylantys metodologiniai prieštaravimai aiškiai atsiskleidè ir mūsų šalyje, kada buvo gauta užduotis naujai verifikuoti Kuršių nerijos nacionalinio parko IVV. (Kavaliauskas, 2010; Piekienė, 2013; Retrospektyvinis Kuršių..., 2014; Povilanskas, 2016; Braškytė, Prapiestiené, 2018 ir kt.).

Antra vertus, pasaulinè IVV nustatymo metodologija iš esmès gali būti taikoma atskirų nacionalinių parkų vertinimui ir netinka jų vidinių kraštovaizdžio teritorinių vienetų vertei nustatyti, todèl teko peržvelgti kai kurių nacionalinių-regioninių kraštovaizdžio vienetų kompleksinio vertinimo metodikų pavyzdžius, atstovaujančius kraštovaizdžio kompleksinio vertinimo empirinei praktikai. Pavyzdžiui, Slovenijoje (Ministry for the..., 1998) vykdomas joje nustatytų trijų lygmenų kraštovaizdžio vienetų kokybès vertinimas, kuriame naudojami tokie kriterijai: a) natūralumo išsaugojimas, b) ìvairovè, c) erdvinè tvarka (reguliarumas), d) harmonija (žemènaudos santykis su gamtine kraštovaizdžio struktūra), e) simbolinè-asociacinè gamtinių ir kultūrinių elementų reikšmè. Vertinimui naudojamos pagal kiekvieną kriterijų parengtos penkiabalès skalès, kur aukščiausia kriterijaus vertė žymima 1, o mažiausia - 5. Konkreti vertinimo metodika ir galutiniai aprašai varijuoja pagal kraštovaizdžio vienetų lygmenis (aukščiausiame lygmenyje akcentuojama homogeniškumas ir įvairove, viduriniame - atpažistamumas ir tapatumas, lokaliniame - sudedamieji kraštovaizdžio komponentai ir mozikiškumas).

Katalonijos kraštovaizdžio tyrimuose taip pat didelis demesys skiriamas kraštovaizdžio vertinimui (Landscape observatory..., 2016). Kraštovaizdžio teritorinių vienetų (naudojama vieno lygmens sistema) vertė nustatoma pagal įvairius požymius: a) gamtinius, lemiančius aplinkos kokybę ir gamtinę ar ekologinę vertę, b) estetinius, lemiančius grožio pojūtị (konfigūracija, žemènaudų mozaikos, unikalumas), c) istorinị atrakcingumą, d) rekreacinị atraktyvumą, d) simbolinę arba asociacinę svarbą, e) ūkinị produktyvumą. Apibendrinat vertinimus išskiriamos kraštovaizdžio teritorijos, 
svarbios sudarant planus, reguliuojant gamtinius išteklius, geologinei, kultūrinei aplinkosaugai, steigiant Europos ir pasaulio saugomas teritorijas. Atskirai nagrinėjama kraštovaizdžio struktūros ir jos elementų meninè raiška, kraštovaizdžio dinamikos atpažistamumas, apžvalgos taškų sklaida ir esami bei galimi maršrutai (itineraries). Galutinis kraštovaizdžio vienetų vertinimas pateikiamas pagal SWOT metodiką, išskiriant stiprybes, silpnybes, galimybes ir grèsmes. Vertinimai baigiami uždavinių, skirtų kraštovaizdžio kokybei gerinti (landscape quality objectives), sąrašais ir jų aprašymais ịvardijant naudojamus kriterijus bei veiksmus. Pažymetina, kad kiekvienas kraštovaizdžio aprašas (Katalogas) privalo turèti tokius vertinamuosius stambaus mastelio (A0 formato) žemèlapius: a) kraštovaizdžio matomumo (reljefo polinkio kampai, ekspozicija, apžvalgos taškai), b) gamtinès ir ekologinès verčių, c) estetinès vertès, d) istorinès vertès, e) ūkinès vertès, f) socialinio naudojimo (rekreacinè) vertès, g) simbolinès-asociacinès vertès, h) kraštovaizdžio dinamikos raiškos.

Mūsų šalies patirtis kraštovaizdžio kokybès vertinimo (kvalimetrijos) sferoje yra gana gera, ypač rekreacinès ir vizualinès vertès nustatymo (Stauskas, 1966; Kavaliauskas, 1970; Budriūnas, Eringis, 2000; Stauskas, Tutlyte, 2001; Daniulaitis, Kamičaitytè-Virbašienè, 2002; Kriaučiūnas, 2002; Kamičaitytè-Virbašienè, 2003; Kavaliauskas, 2011; Kalkè, 2014, ir kt.). Nesant galimybių išsamiau pristatyti atskirus tokių vertinimų pavyzdžius pažymèsime tik dažniausiai juose naudojamus kriterijus. Tai funkcionalumas (fizinis / technologinis tinkamumas), gyvybingumas, struktūros ịvairovè, raiškumas, prasmingumas, tapatumas, harmoningumas, originalumas, sveikumas ir kt.

Kur kas mažesnè patirtis vertinant saugomų teritorijų kraštovaizdžio konservacinę kokybę, kur turime tiek šią kokybę bandančių reglamentuoti teisinių aktų (Etnoarchitektūros vertinimo..., 2004; Gamtos paveldo..., 2009; Nekilnojamųjų kultūros..., 2016), tiek atskirų mokslinių samprotavimų ar pasiūlymų (Bučas, 2006; Mikalauskas, 2012; Petrušonis, 2012; Kavaliauskas, Veteikis, 2014 ir kt.). Pažymètina, kad mūsų šalyje vertinimo teisès aktuose kalbama ne apie IVV, o apie gamtos ir kultūros paveldo objektų santykinio reikšmingumo nustatymą. Gamtos paveldo objektai vertinami (Gamtos paveldo..., 2009) pagal kiekybinius (dydis, amžius, kiekis ir pan.) bei kokybinius (genezé, forma, sudetis ir pan.) parametrus (savybes), kur reikšmingumas nustatomas atsižvelgiant i parametrų (savybių) visumą pagal jų svarbumo (gamtinę, informacinę, mokslinę, pažintinę reikšmes), retumo (išlikimo lygmuo) ir išskirtinumo (išskirtinių savybių turèjimas) kriterijus, lyginant juos su kitais panašiais žinomais objektais. Iš gautų duomenų nustatomas reikšmingumo lygmuo: nacionalinis, regioninis arba vietinis.

Nekilnojamojo kultūros paveldo objektams ir vietovèms (Nekilnojamųjų kultūros..., 2016) vertinimo procesas apima: a) amžiaus cenzo ir autentiškumo patikrą pagal vertingųjų savybių pobūdị, b) reikšmingumo buvimo nustatymą, c) saugomos teritorijos ir apsaugos zonos apibrèžimą; d) reikšmingumo lygmens nustatymą. Reikšmingumas nustatomas atsižvelgiant $\mathfrak{i}$ vertingųjų savybių visumą pagal tipiškumo, svarbumo, retumo ir unikalumo kriterijus. Deja, visa ši teisinio vertinimo sistema turi konservacinę orientaciją ir yra pritaikyta saugotiniems kompaktiškiems objektams ar nedidelèms zonoms nustatyti. Ji ne itin tinka tokių stambiu ir sudètingu saugomų teritorijų kaip nacionalinių ar regioninių parkų kraštovaizdžio valorizacijai, ypač atskirų regioninio lygmens kraštovaizdžio teritorinių vienetų kompleksiniam vertinimui. Todèl atsirado poreikis ieškoti kitų metodinių kelių, labiau atitinkančių tyrimo tikslus ir teritorinę specifiką.

\section{NAUDOTA KRAŠTOVAIZDŽIO IŠSKIRTINUMO TYRIMŲ METODIKA}

Lietuvos valstybinių parkų kraštovaizdžio struktūros išskirtinumas pristatomame darbe (Valstybinių parkų..., 2018-2019) buvo vertintas dviem aspektais: 1) pagal kraštovaizdžio įvairovès lygị ir 2) pagal išskirtų vidinių teritorinių vienetų (apylinkių / vietovių) kraštovaizdžio kompleksinę vertę.

Pirmuoju atveju kraštovaizdžio įvairovès teritorinę diferenciaciją kiekybiškai apibendrino tokia galimų jos rodiklių sistema*:

I. Ivairovès teritorinio diferenciavimo rodikliai (kraštovaizdžio apylinkių lygmuo):

1) $K^{r b}$ (bendrosios regioninès įvairovès rodiklis) $=\mathrm{Na}$ (apylinkių skaičius), [6-66];

\footnotetext{
* Laužtiniuose skliaustuose nurodomi atskirų îvairovès rodiklių
} reikšmių diapazonai. 
2) $K_{a}^{r s}$ (santykinès regioninès įvairovès rodiklis) $=\mathrm{Na}$ (apylinkių skaičius) / S (RP plotas tūkst. ha), [0,81-3,12].

II Itvairovès tipologinio diferenciavimo rodikliai:

3) $K_{t g}^{b}$ (bendrosios tipologinès grupinès ịvairovés rodiklis) $=\mathrm{Ng}$ (tipologinių grupių skaičius), [4-13];

4) $K_{t g}^{s}$ (santykinès tipologinès grupinès ịvairovès rodiklis) $=\mathrm{Ng}$ (tipologiniu grupių skaičius) / S, [0,15-2,38];

5) $K_{t r}^{b}$ (bendrosios tipologinès rūšinès ịvairovès rodiklis) $=\mathrm{Nr}$ (tipologinių rūšių skaičius), [10-33];

6) $K_{t r}^{s}$ (santykinès tipologinès rūšinès įvairovès rodiklis) $=\mathrm{Nr}$ (tipologinių rūšių skaičius) / $\mathrm{S}$, [0,42-8,52];

7) $K^{b}{ }_{i}$ (integruotas bendrosios tipologinès ịvairovès rodiklis) $=0,6 \mathrm{Ng}+0,4 \mathrm{Nr},[6,4-17,2]$;

8) $K_{i}^{s}$ (integruotas santykinès tipologinès ịvairovès rodiklis $)=(0,6 \mathrm{Ng}+0,4 \mathrm{Nr}) / \mathrm{S},[0,23-6,29]$.

III. Kraštovaizdžio įvairovès atraminiai tipologiniai indeksai (kraštovaizdžio apylinkių lygmuo):

9) GDI (gamtinès diferenciacijos indeksas) $=\mathrm{Mg}$ (gamtinių vienetų skaičius) / S, [1,5017,62];

10) SDI (sukultūrinimo diferenciacijos indeksas) $=\mathrm{Ms}$ (sukultūrinimo vienetų skaičius) / S, [0,85-7,61];

11) BDI (bendras suminès diferenciacijos indeksas) = GDI + SDI, [3,04-25,23].

Pažymètina, kad kraštovaizdžio morfologinès struktūros įvairové yra daugiaplanė savybè, kuri gali būti matuojama ịvairiais rodikliais, nuo jų ir priklauso jos interpretacija. Be to, kaip parode šalies VP kraštovaizdžio analize, patys šie rodikliai savo reikšmėmis atskiruose nacionaliniuose ar regioniniuose parkuose gana smarkiai įvairuoja, tad visada gali kilti jų pasirinkimo problema.

Valstybinių parkų morfologinès struktūros išskirtinès įvairovès vertinimo pagrindas - pagal rodiklių sklaidą nustatytą išskirtinę kraštovaizdžio ìvairovès kategoriją pasiekusių priimtų rodiklių 3 kvalimetrinèse jų grupèse sistema, t. y:

A - santykinès ịvairovès (informacinio tankio) rodikliai ir jų išskirtinès reikšmès:

- santykinès regioninès įvairovès rodiklis $-K_{a}^{r s}>2$;

- santykinès tipologinès grupinès ịvairovès rodiklis $-K_{t g}^{s}>1$;
- santykinès tipologinès rūšinès ịvairovès rodiklis $-K_{t}^{s}>1$;

- integruotas santykinès tipologinès ịvairovés rodiklis $-K_{i}^{s}>1$.

$\mathrm{B}$ - bendrosios ịvairovès (informacinès agregacijos) rodikliai ir jų išskirtinès reikšmès:

- bendrosios regioninès ịvairovès rodiklis - $K^{r b}>30$;

- bendrosios tipologinès grupinès įvairovès rodiklis $-K_{t g}^{b}>10$;

- bendrosios tipologinès rūšinès įvairovès rodiklis $-K_{t r}^{s}>20$;

- integruotas bendrosios tipologinès ịvairovès rodiklis $-K^{b}>15$.

C - teritorinès diferenciacijos (informacinès sklaidos) rodikliai ir jų išskirtinès reikšmès:

- gamtinès teritorinès diferenciacijos rodiklis - GDI > 100;

- $\quad$ sukultūrinimo teritorinès diferenciacijos rodiklis - SDI > 50 .

Antruoju atveju, nustatant kraštovaizdžio teritorinių vienetų kompleksinę vertę atskirų valstybinių parkų ribose, teko sudaryti geokvalimetrinių darbų patirtimi paremtą specialią vertinimo kriterijų sistemą, kurioje buvo išskirtos dvi kriterijų grupès:

1) atraminių objektyvizuotų kriterijų grupé (natūralumas, unikalumas, biologinè svarba, kultūrinè svarba, rekreacinè svarba);

2) papildančių subjektyvizuotų kriterijų grupè (vizualinis raiškumas, struktūros tipiškumas, struktūros harmoningumas, elementų simboliškumas / asociatyvumas, apžvalgos sąlygos).

Kadangi vertinimo metodika buvo rengiama skaičiuojamuoju geokvalimetrijos metodu (Kavaliauskas, 1993) naudojant 4 balų (0-3) sistemą, kiek skirtingą reikšmingumą turinčioms minètoms kriterijų grupèms teko pritaikyti svertinius (reikšmès / svorio) koeficientus. Laikytasi kvalimetrijoje naudojamos taisyklès, kad apjungiamų komponentų reikšmès koeficientų suma būtų lygi vienetui (pirmajai grupei ekspertiniu būdu buvo priskirtas koeficientas lygus 0,6 , antrąjai grupei - 0,4). Taip pat kiekybiškai ar kokybiškai buvo parametrizuoti suteikiami balai pagal visus priimtus kriterijus.

Vertinimo aspektų vertinimo parametrizavimo pavyzdžiai:

Natūralumas - natūralių ir subnatūralių gamtinių naudmenų (miškų, pelkių, vandens telkinių) 
santykinè dalis kraštovaizdžio apylinkèje buvo vertinamas tokiais balais:

3 - >80 \%; 2 - 80-50 \%; 1 - 30-50 \%; $0-<30 \%$.

Biologine svarba - kraštovaizdžio apylinkès svarba biologinès ivvairovès apsaugai buvo vertinama tokiais balais: 3 - apima gamtinius ir perspektyvoje galimus kompleksinius rezervatus; 2 - apima biologinius bei kompleksinius draustinius ir biosferos poligonus; 1 - apima kitus gamtinius draustinius ir biologinio paveldo objektus; 0 - neturi biologiškai svarbių teritorijų ir objektų.

Struktūros harmoningumas - kraštovaizdžio apylinkès morfologinès struktūros elementų suderinamumas buvo vertinamas tokiais balais:

3 - stebima visų vizualinès struktūros elementų dermé; 2 - stebima mažiau reikšmingų vizualinès struktūros elementų disharmonija; 1 - stebima reikšmingų vizualinès struktūros elementų disharmonija; 0 - chaotiška neharmoninga kraštovaizdžio vizualinè struktūra.

Simboliškumas / asociatyvumas - ypatingos semantikos ir asociatyvių elementų buvimas kraštovaizdžio apylinkès vizualinejje struktūroje buvo vertinamas tokiais balais:

3 - yra penki ar daugiau asociacine simboline semantika pasižymintys elementai; 2 - yra trys ar keturi asociacine simboline semantika pasižymintys elementai; 1 - yra tik vienas ar du asociacine simboline semantika pasižymintys elementai; 0 - kraštovaizdžio struktūroje nèra asociacine simboline semantika pasižyminčių elementų.

Specifinè padètis susidare vertinant istoriniu valstybinių parkų (Trakų INP ir Dieveniškių RP) kraštovaizdị. Siekiant atsižvelgti i jų vertès specifiką, kada prioritetas turi būti teikiamas istorinèms-kultūrinėms vertybėms, teko kiek adaptuoti naudojamų vertès kriterijų sistemą, kuri šiuose parkuose tapo tokia:

1) atraminiai kriterijai, kai $k=0,6$ (istorinis autentiškumas, unikalumas, elementų simboliškumas, kultūrinè svarba, rekreacinè svarba);

2) papildantys kriterijai, kai $k=0,4$ (vizualinis raiškumas, struktūros tipiškumas, struktūros harmoningumas, apžvalgos sąlygos, biologinè svarba).

Istorinių-kultūrinių aspektų vertinimo parametrizavimas:

Istorinis autentiškumas - saugomų ar saugotinų kultūros vertybių atitikimas jų atstovauja- miems istoriniams laikmečiams buvo vertinamas tokiais balais:

3 - visiškas atitikimas istoriniam etalonui; 2 - medžiagos ir formų atitikimas; 1 - bendro pobūdžio atitikimas; 0 - neišlikę autentiškų bruožų.

Kultūrinè svarba - kraštovaizdžio apylinkès svarba kultūrinès paveldosaugos kontekste buvo vertinamas tokiais balais:

3 - apima kultūrinius ir perspektyvoje galimus kompleksinius rezervatus; 2 - apima kultūrinio profilio draustinius ar saugomas vietoves; 1 - apima svarbių kultūros paveldo objektų turinčias teritorijas; 0 - neturi kultūros paveldo apsaugai svarbių teritorijų ar objektų.

Apskritai bendrąją metodinę VP kraštovaizdžio vienetų morfostruktūros kompleksinès vertès $(X)$ apskaičiavimo formulę galima pateikti kaip:

$$
X=0,6 \Sigma A i+0,4 \Sigma P i,
$$

$A i$ - atskirų (i) atraminių kriterijų vertinimas balais,

$P i$ - atskirų (i) papildančių kriterijų vertinimas balais.

Bendras galimų gauti balų skaičius yra 15 (devyni pagal atraminius ir šeši pagal papildančius kriterijus).

Baigiamoji kraštovaizdžio teritorinių vienetų kompleksinio vertinimo fazė yra jų santykinės reikšmès (išskirtinumo) nustatymas, naudojantis gautomis vertinimo procese balų sumomis. Buvo priimta tokia kvalimetrinė kraštovaizdžio vienetu kompleksinès vertès kategorizacija:

I - išskirtinė (aukščiausia) kategorija - kraštovaizdžio apylinkè / vietovè surenka daugiau kaip du trečdalius visų galimų gauti balų (t. y. >10);

II - aukšta kategorija - kraštovaizdžio apylinkè / vietovè surenka nuo pusès iki dviejų trečdalių visų galimų balų (8-10);

III - vidutinè kategorija - kraštovaizdžio apylinkè / vietové surenka nuo trečdalio iki pusès visų galimų balų (5-7);

IV - žemesnè nei vidutinè kategorija - kraštovaizdžio apylinkė / vietovė surenka mažiau nei trečdalị visų galimų balų (iki 4).

Tyrimas parodè, kad Lietuvos valstybiniuose parkuose būdingas I ir II kompleksinès vertès kategorijų kraštovaizdis, o IV kategorija sutinkama daugiausia parkų pakraščiuose ir yra kraštovaizdžio ne visai optimalaus ribų nustatymo rezultatas. 


\section{VALSTYBINIŲ PARKŲ KRAŠTOVAIZDŽIO MORFOSTRUKTŪROS PALYGINAMOJO VERTINIMO REZULTATŲ APIBENDRINIMAS}

Išskirti kraštovaizdžio morfologinès struktūros teritoriniai vienetai ir jų kartografinis lokalizavimas sudaré galimybes vykdyti ne tik matematinę-statistinę kraštovaizdžio morfostruktūros požymių sklaidos analizę valstybinių parkų viduje, bet ir atlikti palyginamuosius apibendrinimus tarp atskirų valstybinių parkų.

Palyginamoji išskirtinẻ kraštovaizdžio struktūros įvairovè. VP palyginamosios išskirtinès įvairovès nustatymo pagrindas - visos VP kraštovaizdžio struktūros gautas suminis išskirtinès įvairovès koeficientas (a) pagal formulę:

$$
\alpha=0,5 \mathrm{~A}+0,3 \mathrm{~B}+0,2 \mathrm{C},
$$

A - santykinès ịvairovès (informacinio tankio) rodiklių grupe;

B - bendrosios ịvairovès (informacinès agregacijos) rodikliu grupé;

C - teritorinès diferenciacijos (informacinès sklaidos) rodikliu grupé;

0,$5 ; 03 ; 0,2$ - atskirų rodiklių grupių svertiniai koeficientai.

Pastaba: skaičiuojama pagal VP gautą išskirtinio vertinimo rodiklių skaičių.

Atskiriems nacionaliniams (NP) ir regioniniams (RP) parkams kraštovaizdžio morfostruktūros palyginamojo išskirtinumo kategorija buvo priskiriama pagal apskaičiuoto jų suminio išskirtinès ịvairovès koeficiento ( $\alpha$ ) reikšmes tokiu būdu:

I (aukščiausioji)

$a-[>2]$ Trakų INP, Varnių RP, Kurtuvėnų RP, Pajūrio RP, Rambyno RP, Verkių RP, Pavilnių RP.

II (aukšta)

a - [1-2] Aukštaitijos NP, Žemaitijos NP, Dzūkijos NP, Nemuno kilpų RP, Aukštadvario RP, Anykščių RP, Nemuno deltos RP, Panemunių RP, Neries RP, Labanoro RP, Veisiejų RP, Metelių RP, Salantų RP, Pagramančio RP, Ventos RP, Žagarès RP.

III (standartinè)

$a-[<1]$ Kuršių nerijos NP, Gražutès RP,

Sirvètos RP, Dubysos RP, Asvejos RP, Sartų RP, Kauno marių RP, Vištyčio RP, Biržų RP, Dieveniškių IRP, Tytuvènų RP, Krekenavos RP.
Bendra šalies VP kategorizacija pagal jų kraštovaizdžio morfostruktūros įvairovę parodyta 1 pav. Pažymètina, kad kai kuriuose iš jų aukštą sumini ịvairovès rodikli lèmé santykinè ịvairovè itin priklausoma nuo parko dydžio (Rambyno RP, Pjūrio RP, Verkių RP, Pavilnių RP). Neturètų stebinti santykinai žemas Kuršių nerijos NP vertinimas - tai nulèmè realus jos kraštovaizdžio struktūros monotoniškumas, nepaisant visų jos kraštovaizdžiui skiriamų „ditirambų“.

Palyginamoji išskirtinè kraštovaizdžio struktūros kompleksinè vertė. VP palyginamojo išskirtinumo vertinimo pagrindu buvo priimta atskirų parkų kraštovaizdžio apylinkių kompleksinio vertinimo metu surinkta bendra išskirtinumo balu suma. Taip pat atsižvelgta ị esamų ir planavimo dokumentuose pripažintų perspektyvių nacionalinių ar nacionalinių istorinių parkų atitikimą šių parkų ìstatyminèms koncepcijoms. Papildomi balai buvo skirti: Kuršių nerijos NP - 30, Aukštaitijos NP - 20, Dzūkijos NP - 20, Žemaitijos NP - 10, Trakų INP - 30, Varnių RP (INP) - 20, Anykščių RP (INP) - 10 ir Labanoro RP (10). Suprantama, kad didžiausius balus gavo Kuršiu nerija, o kiti esami ir perspektyviniai valstybiniai parkai - mažesnius.

Atskiriems nacionaliniams ir regioniniams parkams kraštovaizdžio morfostruktūros palyginamoji išskirtinumo kategorija buvo priskiriama pagal apskaičiuotą jų suminị išskirtinès vertès balų skaičių:

I - aukščiausioji

Ia - per 100 balų: Kuršių nerijos NP, Dzūkijos NP, Aukštaitijos NP, Varnių RP/INP/, Labanoro $\mathrm{RP} / \mathrm{NP}$

Ib - 80-100 balų: Žemaitijos NP, Trakų INP, Anykščių RP/INP.

II - aukšta

IIa - 65-80 balų: Aukštadvario RP, Nemuno kilpų RP, Kurtuvènų RP, Panemunių RP;

IIb - 50-65 balų: Salantų RP, Dubysos RP, Veisiejų RP, Pavilnių RP, Gražutès RP, Pagramančio RP, Metelių RP, Ventos RP, Nemuno deltos RP.

III - standartinè

IIIa - 40-50 balų (Kauno marių RP, Asvejos RP, Vištyčio RP, Neries RP, Rambyno RP, Sartų RP, Dieveniškių IRP);

IIIb - iki 40 balų: Verkių RP, Pajūrio RP, Sirvètos RP, Biržų RP, Tytuvènų RP, Krekenavos RP, Žagarès RP. 


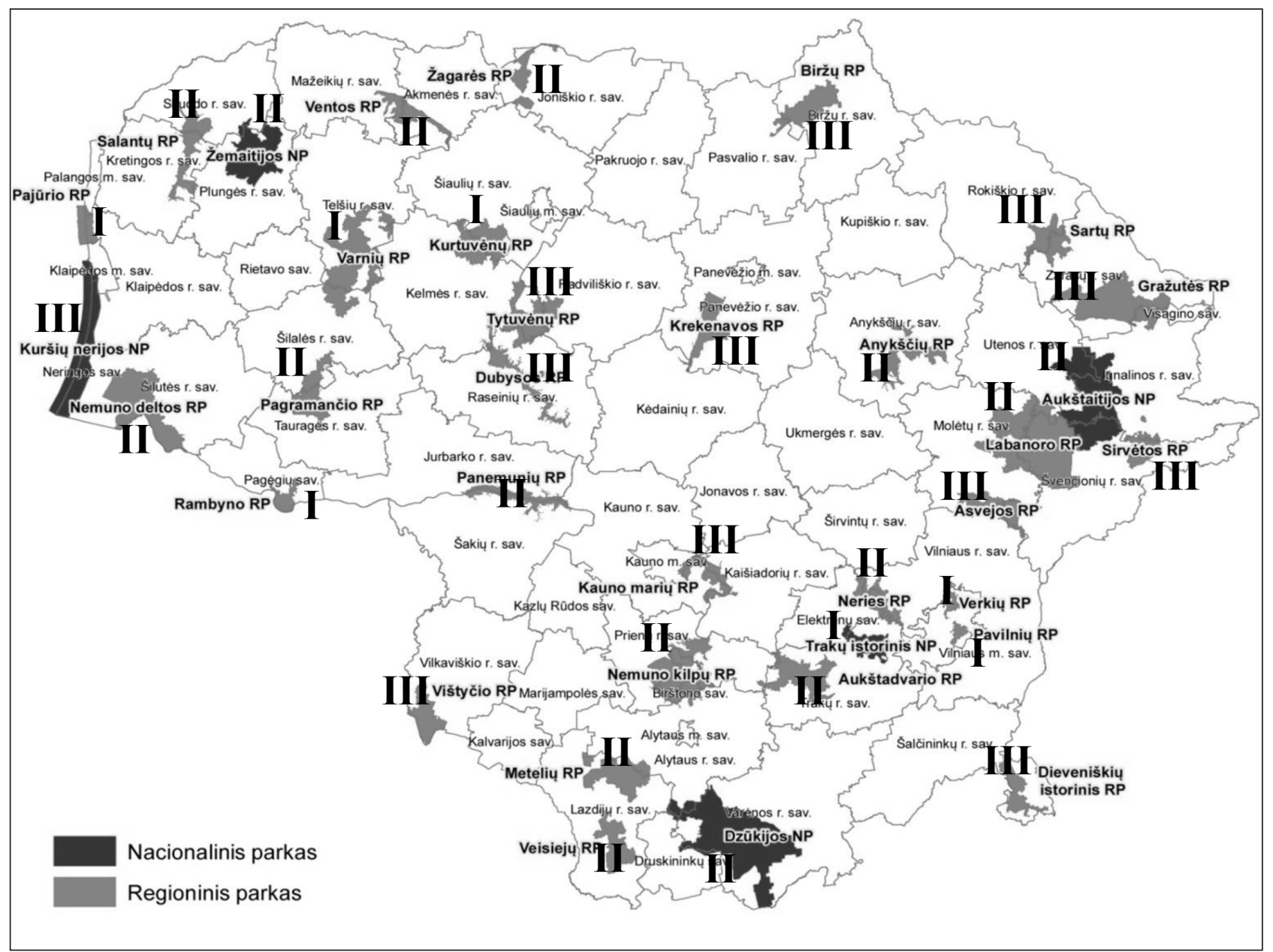

1 pav. Lietuvos nacionalinių ir regioninių parkų pasiskirstymas pagal kraštovaizdžio struktūrinès ịvairovès išskirtinumo kategorijas (I - aukščiausioji, II - aukšta, III - standartinè)

Fig. 1. Categories of outstandingness (I - supreme, II - high, III - standard) on landscape structural diversity of Lithuanian national and regional parks

Gali būti atliekamas ir alternatyvus VP teritorijos palyginamojo išskirtinumo kompleksinis vertinimas pagal: (a) išskirtinius balus gavusių kraštovaizdžio apylinkių plotų suminị procentą arba pagal (b) išskirtinius balus gavusių kraštovaizdžio apylinkių skaičiaus sumini procentą. Atlikti skaičiavimai parodè pirmojo metodo, kaip tiksliau atspindinčio išskirtinos teritorijos realų santykį, prioritetą. Todèl straipsnyje pateikiami tik juo gauti rezultatai.

Atskiriems nacionaliniams ir regioniniams parkams kraštovaizdžio morfostruktūros palyginamoji išskirtinumo kategorija pagal apskaičiuotą jų išskirtinès vertès balus gavusių apylinkių plotų suminị procentą buvo priskiriama tokiu būdu:

I - aukščiausioji

Ia - per 80 \%: Kuršių Nerijos NP, Pavilnių RP;

Ib - 80-100 \%: Nemuno kilpų RP, Anykščių RP, Dubysos RP, Rambyno RP.
II - aukšta

IIa - 40-50 \%: Aukštaitijos NP, Panemunių RP, Kauno marių RP, Salantų RP, Pajūrio RP, Gražutès RP;

IIb - 30-40\%: Aukštadvario RP, Trakų INP, Varnių RP, Verkiu RP, Labanoro RP, Neries RP, Sirvètos RP.

III - standartinè

IIIa - 20-30 \%: Dzūkijos NP, Žemaitijos NP, Kurtuvėnų RP, Nemuno deltos RP, Metelių RP, Sartų RP, Vištyčio RP, Veisiejų RP, Asvejos RP, Dieveniškių IRP, Biržų RP, Ventos RP;

IIIb - <20 \%: Tytuvènų RP, Krekenavos RP, Pagramančio RP, Žagarès RP.

Abiem būdais atliktų VP teritorijų kraštovaizdžio išskirtinumo vertinimai parodè metodų nuostatų ir technologinių ypatumų nulemtus kiek skirtingus rezultatus. Vis dèlto beveik pusès VP rezultatai buvo identiški, trečdaliui aukštesnę kategoriją lèmė kompleksinis 
vertinimas, o penktadaliui vertinimas pagal ploto procentą.

Abiejų metodų rezultatų palyginamoji išklotinè atrodo taip:

1. Abu vertinimai tos pačios kategorijos (16 VP):

[I] - KNNP, Anykščiu RP;

[II] - Panemunių RP, Aukštadvario RP, Gražutès RP, Salantų RP;

[III] - Asvejos RP, Sartų RP, Vištyčio RP, Dieveniškių IRP, Biržų RP, Žagarès RP, Krekenavos RP, Sirvètos RP, Tytuvėnų RP; Krekenavos RP.

2. Vertinimas pagal balus aukštesnis už vertinimą pagal plotus (12 VP):

[I>II] - Aukštaitijos NP, Trakų INP, Varnių RP, Labanoro RP;

[I >III] - Žemaitijos NP, Žemaitijos NP;
[II>III] - Nemuno deltos RP, Kurtuvėnų RP, Veisiejų RP, Metelių RP, Pagramančio RP, Ventos RP.

3. Vertinimas pagal plotus aukštesnis už vertinimą pagal balus (7):

[I>II] - Nemuno kilpų RP, Pavilnių RP, Dubysos RP;

[I>III] - Rambyno RP;

[II>III] - Kauno marių RP, Neries RP, Verkių RP.

Pastaba: vertinimų rezultatai palyginami pagal santykinio išskirtinumo kategorijas [I, II, III].

Konkreti VP išskirtinumo vertinimo kategorijų teritorinè sklaida abiem alternatyviais variantais pateikiama kartoschemoje (2 pav.).

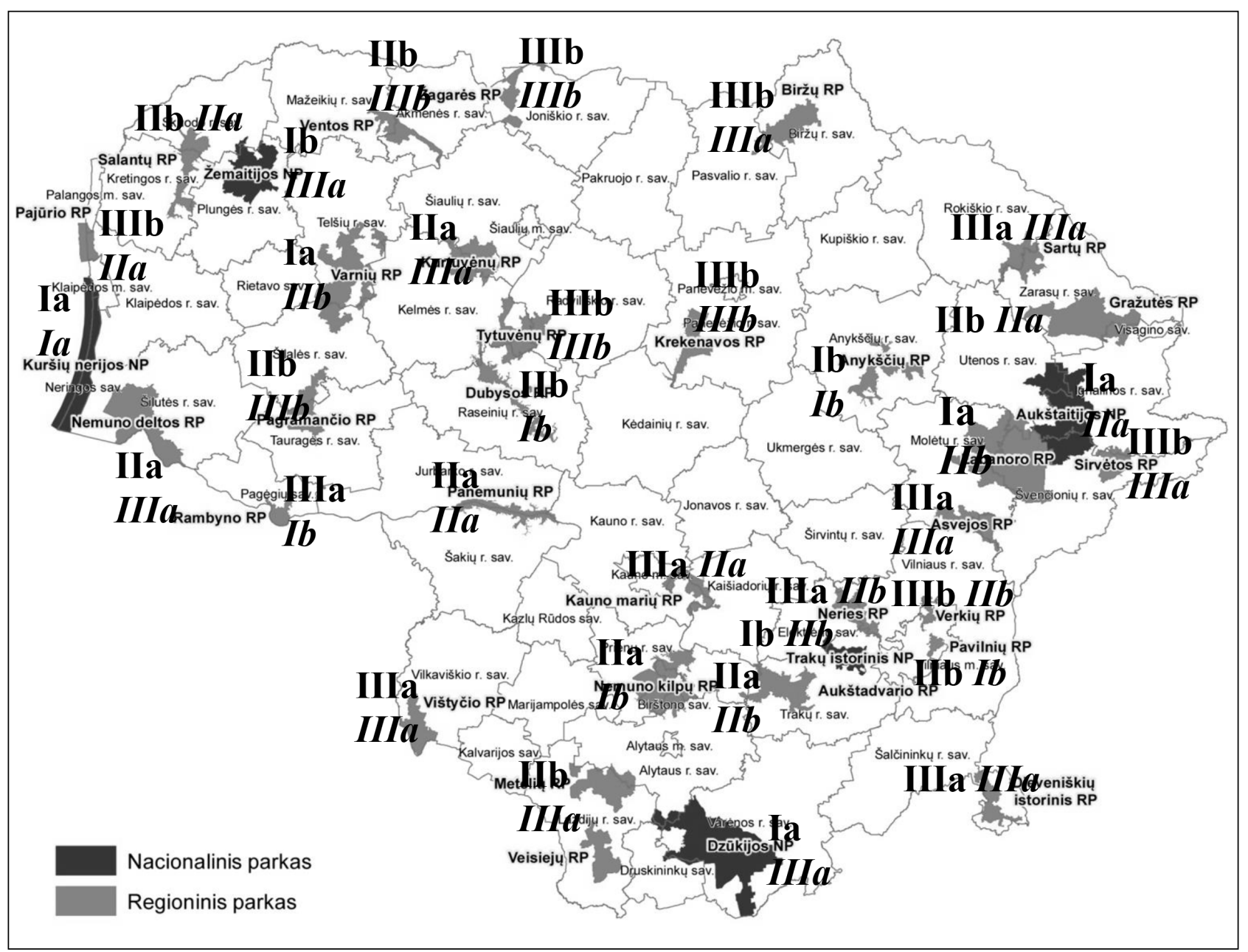

2 pav. Lietuvos nacionalinių (juodi plotai) ir regioninių (pilki plotai) parkų pasiskirstymas pagal kraštovaizdžio struktūros išskirtinumo kategorijas (I - aukščiausioji, II - aukšta, III - standartinè) ir kompleksinę balinę (status šriftas) bei plotinę procentinę (pasviręs šriftas) versijas

Fig. 2. Categories of outstandingness (I - supreme, II - high, III - standard) on landscape structural outstandingness of Lithuanian national (black patterns) and regional (grey patterns) parks according to complex value (normal font) and area percent (italic font) versions 


\section{IŠVADOS}

1. Nacionaliniai ir regioniniai parkai tiek visu plotu, tiek pagal savo vidinius teritorinius kraštovaizdžio vienetus nèra visiškai homogeniški pagal kraštovaizdžio morfostruktūros išskirtinumą, todèl kyla objektyvus kraštotvarkinis būtinumas fiksuoti ir ịvertinti ši netolygumą.

2. Būdinga, kad iki šiol nèra vieningos kraštovaizdžio išskirtinumo nustatymo metodikos ne tik atskirų stambių pasaulio regionų, bet net atskirų šalių. Mažai tikètina, ar tokia metodika, nepaisant norų ir bandymų suteikti tam teisinį reguliavimą, bus sukurta.

3. Kraštovaizdžio išskirtinumą rekomenduojama metodologiškai apibrěžti dviem pagrindiniais aspektais: a) per morfologinès struktūros ịvairovès skirtumus ir b) per nustatytos kraštovaizdžio morfologinès struktūros santykinę kompleksinę vertę.

4. Pirmuoju atveju susiduriame su visos VP kraštovaizdžio struktūros nustatymo galimų rodiklių ivairove, todèl iškyla realus poreikis apskaičiuoti sumini išskirtinès ịvairovès koeficientą, turintị vertinti ir integruoti naudotinus atskirus informacinio tankio, informacinès agregacijos ir informacinès sklaidos rodiklius.

5. Antruoju atveju tenka spręsti multikriterinès kvalimetrijos uždavinį, kuriame kraštovaizdžio morfostruktūrą tenka ịvertinti atsižvelgiant i ìvairius kokybiškai skirtingus vertinimo kriterijus, o nustatant skaičiuojamojo kvalimetrijos metodo būdu gautų palyginamojo santykinio vertinimo rezultatų (suminio balų skaičiaus) kategorijas laikytis vadinamosios „elektorinès“ taisyklès, t. y. aukščiausiąją kategoriją suteikti teritorijoms, surinkusioms daugiau nei du trečdalius galimų gauti vertinimo taškų (balų), aukštą kategoriją - surenkančioms daugumą (pusę) galimų taškų, ir standartinę kategoriją - visoms likusioms teritorijoms.

6. Istoriniams nacionaliniams ir istoriniams regioniniams parkams rekomenduojama taikyti ju specifikai (istorinių kultūrinių vertybių prioritetui) adaptuotą vertimo kriterijų sistemą.

7. Gali būti atliekamas ir alternatyvus VP teritorijos palyginamojo išskirtinumo kompleksinis vertinimas pagal: (a) išskirtinius balus gavusių kraštovaizdžio apylinkių plotų sumini procentą arba pagal (b) išskirtinius balus gavusių kraštovaizdžio apylinkių skaičiaus suminị procentą.
8. Gauti konkretaus Lietuvos VP palyginamojo vertinimo rezultatai apie kraštovaizdžio morfologinès struktūros išskirtinumą parodè, kad vertinant struktūrinę ịvairovę pirmauja Trakų istorinis nacionalinis bei Varnių, Kurtuvėnų, Verkių, Pajūrio, Rambyno ir Pavilnių regioniniai parkai. Pagal kraštovaizdžio struktūros kompleksinę vertę išsiskiria Kuršių nerijos, Aukštaitijos ir Žemaitijos nacionaliniai, Trakų istorinis nacionalinis bei Varnių, Anykščių, Labanoro, Nemuno kilpų, Pavilnių, Dubysos ir Rambyno regioniniai parkai.

Gauta 20190814

Priimta 20191008

\section{LITERATŪRA}

1. Bučas J. 2006. Žaliojo kultūros paveldo problema. Urbanistika ir architektūra. 33(1): 19-29.

2. Budriūnas A. R., Eringis K. 2000. Kraštovaizdžio estetinio rekreacinio vertinimo metodika. Vilnius: BI leidykla.

3. Braškytè L., Prapiestienè R. 2018. Kuršiu nerijos nacionalinio parko paveldo būklès vertinimas. Geologija. Geografija. 4(1): 42-54.

4. Calera A. 2014. Reflections on the landscape: Theory and management in Europe. Landscape Anthropology in European Protected Areas. Reports from the University of Stavanger. 44: 13-28.

5. Daniulaitis G. J., Kamičaitytė-Virbašienè J. 2002. Kraštovaizdžio estetinès ir vizualinès kokybès problema kraštotvarkoje. Kraštovaizdžio vizualine kokybe. Kaunas. 16-23.

6. Deckha N. 1999. Historic preservation and the cultural politics of the American downtown. City \& Society. 11(1-2): 193-200.

7. Droste B., Placher H., Rossler M. 1995. Cultural Landscapes of Universal Value. Stuttgart.

8. Etnoarchitektūros vertinimo kriterijai ir tvarka. Patvirtinta Kultūros vertybiu apsaugos departamento prie LR kultūros ministerijos direktoriaus 2004 m. vasario 20 d. ịsakymu Nr. I-35 (VŽ, 2004, Nr. 40-1320).

9. European landscape convention and explanatory report. 2001. Vilnius: LR Aplinkos ministerija.

10. Europos kraštovaizdžio konvencija. Susije dokumentai. 2012. Vilnius: LR Aplinkos ministerija. Ratifikuota 2002-10-03.

11. Feilden B. M., Johilehto J. 1993. Management Guidelines for World Cultural Heritage Sites. Roma RM: ICCROM.

12. Gamtos paveldo objektu vertinimo ir reikšmingumo nustatymo kriteriju aprašas. Patvirtintas LR aplinkos ministro 2009 m. liepos 8 d. issakymu Nr. D1393. Žin., 2009, Nr. 83-3476. 
13. Kalkė D. 2014. Kraštovaizdžio estetinio potencialo tyrimų Lietuvoje apžvalga. K. Šešelgio skaitymai. 6(3): 273-281.

14. Kamičaitytè-Virbašienè J. 2003. Kraštovaizdžio vizualinès kokybès reguliavimas kraštotvarkoje (Lietuvos pavyzdžiu): daktaro disertacijos santrauka. Kaunas.

15. Kavaliauskas P. 1970. Kraštovaizdžio rekreacinio bonitavimo principai. Geografija ir geologija. 8: 43-52.

16. Kavaliauskas P. 1974. Kraštovaizdžio rekreacinio bonitavimo sistemų metodinè apžvalga. Lietuvos TSR architektūros klausimai. 4: 73-86.

17. Kavaliauskas P., Veteikis D. 2014. Defining landscape quality objectives for the landscapes identified in protected areas. Reports from the University of Stavanger. 44: 29-58.

18. Kavaliauskas P. 1993. Taikomųų teritorijos tyrimų metodologija. Geografija. 29: 105-115.

19. Kavaliauskas P. 2010. Kuršių nerijos Išskirtinès visuotinès vertès nustatymo pagrindai. Kuršiu nerijos kaip UNESCO Pasaulio paveldo ateitis. Tarptautinis seminaras, Nida.

20. Kavaliauskas P. 2011. Kraštovaizdžio samprata ir planavimas: mokomoji knyga. Vilnius: VU. Prieiga per internetą: http://www1151.vu.lt/leidiniai [žiūrèta 2018-05-16; 2019-07-22].

21. Kavaliauskas P. ir kt. 2013. Lietuvos Respublikos kraštovaizdžio erdvinès struktūros ivvairoves ir jos tipu identifikavimo studija. I-II dalys. Vilnius: LR Aplinkos ministerija.

22. Kavaliauskas P., Kažienè A. ir kt. 2015. Nacionalinis kraštovaizdžio tvarkymo planas. Sprendiniai ir rekomendacijos. 2015. UAB „Urbanistika“ - Lietuvos geografų draugija, Vilnius.

23. Kavaliauskas P. 2014. Kraštovaizdžio planavimo metodologijos problema. Geografija. 50(2): 45-57.

24. Kavaliauskas P. 2019. Lietuvos nacionalinių ir regioninių parkų morfostruktūros analizė kraštovaizdžio geografijos aspektu: 1. Metodologija. Geografijos metraštis. 52.

25. Kraštovaizdžio schemu ir planu (buv. tvarkymo specialiuju planu) rengimo taisykliu naujos redakcijos projektas. 2013. Všt "Gamtos paveldo fondas“.

26. Kraštovaizdžio tvarkymo specialiujų planu rengimo taisykles. Patvirtintos 2004-05-05 Lietuvos Respublikos aplinkos ministro įsakymu Nr. D1246. Žin., 20004, Nr. 79-2811.

27. Nogue J., Sala P., Grau J. 2016. The Landscape Catalogues of Catalonia. Methodology. Edited by: Landscape Observatory of Catalonia. Barselona: ATLL.

28. Lietuvos nacionalinè UNESCO komisija. 2006. Pasaulio paveldo konvencijos igyvendinimo gairès. Vilnius.

29. Lietuvos Respublikos kraštovaizdžio politikos krypčiu aprašas. Patvirtintas 2004-12-01 Lietuvos Respublikos Vyriausybès nutarimu Nr. 1526. Žin., 2004, Nr. 174-6443; 2005, Nr. 64-2302.
30. Lietuvos Respublikos teritoriju planavimo istatymo pakeitimo istatymas. Patvirtintas 2013-0627 Lietuvos Respublikos Vyriausybès nutarimu Nr. XII-407. Žin., 2013, Nr. 76-3824.

31. Mikalauskas G. 2012. Žvilgsnis it Lietuvos saugomus gamtos paveldo objektus. Geologijos akiračiai. 4: 28-33.

32. Marušič J., Jančič M. 1998. Regional Distribution of Landscape Types of Slovenia. Methodological Bases. Ljubljana: Ministry of the Environment and Physical Planning.

33. Nekilnojamuju kultūros vertybiu vertinimo, atrankos ir reikšmingumo lygmens nustatymo kriteriju aprašas. Nauja redakcija patvirtinta LR kultūros ministro $2016 \mathrm{~m}$. spalio 4 d. ìsakymu Nr. IV-752 (TAR 2016-10-04, i. k. 2016-24473).

34. Petrušonis V. 2012. Kultūros paveldo vertinimo metodologines perspektyvos bendruju moksliniu paradigmu kaitos kontekste. J of Architecture and Urbanism. 36(1): 1-8.

35. Piekienè N. 2013. Kuršių nerijos kraštovaizdis. Tapatybès išraiška. K. Šešelgio skaitymai. Vilnius.

36. Povilanskas R. 2016. Kuršiu nerijos išskirtinė visuotinè vertè: alternatyvus požiūris. Kuršių nerijos kraštovaizdžio pokyčiai. Kuršių nerijos nacionalinio parko 25-mečio konferencija, Nida.

37. Recommendation $C M / \operatorname{Rec}(2008) 3$ of the Committee of Ministers to Member States on the Guidelines for the Implementation of the European Landscape Convention. 2008. Brussels: Council of Europe.

38. Retrospektyvinis Kuršiu nerijos išskirtinès visuotinès vertès aprašas. 2014. Patvirtintas UNESCO Pasaulio paveldo komiteto 38 sesijos nutarimu Nr. 8E (autentiškas vertimas 2017-02-20).

39. Roger A. 2008. Vida y muerte de los paisajes. Valores estéticos, valores ecológicos. Paysaje $y$ teoría. Madrid. 67-85.

40. Stauskas V. 1966. Landšafto įvertinimo metodika, planuojant poilsio rajonus. Lietuvos TSR architektūros klausimai. 3: 184-206.

41. Stauskas V., Tutlytė J. 2001. Lietuvos kraštovaizdžio estetinis potencialas ir jo santykis su rekreacinių interesų zonomis. Kultūrinių kraštovaizdžių apskaita ir apsauga. Pranešimų medžiaga. Kaunas. 13-17.

42. Decision 38 COM 8E: Adoption of Retrospective Statements of Outstanding Universal Value. 2014. The World Heritage Committee.

43. Operational Guidelines for the Implementation of the Word Heritage Convention. 2008. Paris: UNWHC.

44. Valstybinių parkų kraštovaizdžio struktūros schemu parengimas. 2018-2019. VI Valstybès žemès fondas, Vilnius.

45. Washer D. M. (ed.). 2005. European Landscape Character Area. Typologies, Cartography and Indicators for the Assessment of Sustainable Landscapes. Final Project Report from the EU's Landscape Europe Secretariat. Wageningen, The Netherlands. 
Paulius Kavaliauskas, Nedmantas Kavaliauskas

\section{MORPHOSTRUCTURAL ANALYSIS OF LITHU- ANIAN NATIONAL AND REGIONAL PARKS:} 2. OUTSTANDINGNESS OF THE TERRITORY

\section{Sum mary}

National and regional parks, both in their total area and in their internal territorial landscape units, are not completely homogeneous in terms of the distinctness of the landscape morphostructure, and therefore there is an objective landscape management need to assess and capture this imbalance. It is typical that until now there is no unified methodology for establishing landscape outstandingness not only in the context of individual large regions of the world, but even within individual countries, and it is unlikely that such a methodology will be developed, despite the desires and attempts to regulate it with legal instruments.

The article presents the second part of special research carried out in Lithuania in 2018-2019, aimed at identifying national and regional parks with the highest (outstanding) value or significance and carrying out comparative analysis of individual parks. The results of the analysis of landscape morphological structure of all national and regional parks of Lithuania presents the peculiarities of the concept of landscape outstandingness, attempts to identify it and the Lithuanian experience in this field.

It is recommended that the outstandingness of a landscape be defined methodologically in two main ways: (a) through differences in the diversity of morphological structure, and (b) through the relative complexity of the established landscape morphological structure. In the first case, we face a variety of possible indicators for defining the landscape structure of the entire national or regional parks, resulting in a real need to compute a cumulative coefficient of exceptional diversity to evaluate and integrate the individual indicators of information density, aggregation, and dissemination. This total exceptional diversity coefficient $(\alpha)$ was calculated according to the formula:

$$
a=0.5 \mathrm{~A}+0.3 \mathrm{~B}+0.2 \mathrm{C} \text {, }
$$

where A - a set of relative diversity (information density) indicators,

B - aggregate diversity (information aggregation) indicator group,

C - group of indicators of territorial differentiation (dissemination of information),

$0.5 ; 03 ; 0.2$ - weighting coefficients for individual indicator groups.

In the second case, we have to solve the problem of multicriteria qualimetry, where the landscape morphostructure has to pass through the qualitatively different evaluation criteria, and when defining the categories of comparative relative evaluation results (cumulative scores) by a computational qualimetry method, i.e. give the highest category to areas that have scored more than two-thirds of the points available, the high category to most (over half) of the available points, and the standard category to all remaining areas. Historic national and historic regional parks are recommended to apply a system of translation criteria adopted to their specificity (priority of historical cultural values). Alternative complexity assessment of the comparative outstandingness of a national or regional parks territory may also be conducted based on: (a) the sum of the percentage of landscaped areas that have received exceptional scores, or (b) the sum of the number of landscapes that have received exclusive scores.

The results of the specific comparative evaluation of Lithuanian national and regional parks in the context of the exceptional morphological structure of the landscape showed that the Trakai Historic National Park and Varniai, Kurtuvènai, Verkiai, Pajūris, Rambynas and Pavilniai regional parks are leading in terms of structural diversity. The Curonian Spit, Aukštaitija and Žemaitija national, as well as Trakai historic national and Varniai, Anykščiai, Labanoras, Nemunas loops, Pavilniai, Dubysa and Rambynas regional parks stand out in terms of the complex value of the landscape structure.

Keywords: national and regional parks, landscape morphostructure, landscape diversity, comprehensive value of the landscape, outstandingness of the territory 